\title{
Hubungan Kadar Interleukin 6 Serum dan Klasifikasi CT Marshal pada Penderita Cedera Otak Berat Akibat Trauma
}

\author{
${ }^{1}$ Mervin Manginte, ${ }^{2}$ Eko Prasetyo, ${ }^{2}$ Maximillian Ch. Oley
}

\author{
${ }^{1}$ PPDS Ilmu Bedah Fakultas Kedokteran Universitas Sam Ratulangi Manado \\ ${ }^{2}$ Divisi Bedah Saraf Bagian Ilmu Bedah Universitas Sam Ratulangi/RSUP Prof. Dr. R. D. \\ Kandou Manado \\ Email: M_zip@hotmail.com
}

\begin{abstract}
Increase of interleukin 6 (IL-6) level occurs in the brain after traumatic brain injury (TBI), however, studies about IL-6 as a prodictor based on CT-scan is still limited. This study was aimed to evaluate the relationship between serum IL-6 level and CT Marshall classification in patients with severe TBI. This was an observational study with a cross sectional design. There were 20 patients with severe TBI admitted at the Emergency Surgery Installation of Prof. Dr. R. D. Kandou Hospital Manado in this study. CT-scan was performed on them to determine the CT Marshall classification and to categorize the hemorrhage location (extra-axial, intra-axial, both), hemisphere (midline/diffuse, dextral, sinistral), and area (frontal, parietal, temporal, occipital, multiple). Venous blood sample used for IL-6 examination was drawn less than 24 hours after trauma. The results showed that mean IL-6 level was 22.0060 $\mathrm{pg} / \mathrm{mL}$ (SD $4.64494 \mathrm{pg} / \mathrm{mL}$ ). Patients were distributed relatively uniform in 4 detected categories (diffuse injury II, III, V, and VI) of CT Marshall classification. Final regression model consisted of IL-6, age, and temporal injury as predictors. The Spearman coefficient correlation showed $\mathrm{rs}=-0.005(P=0.491)$. Conclusion: There was no significant relationship between serum Il-6 level and CT Marshall classification, albeit, both of them increased consistantly following the severity of TBI and could be potential predictors to determine the prognosis of severe TBI patients.
\end{abstract}

Keywords: IL-6, CT Marshall, severe TBI

\begin{abstract}
Abstrak: Pada cedera otak berat akibat trauma (COBT) terjadi peningkatan ekspresi IL-6 di otak namun penelitian mengenai kemampuannya untuk memrediksi hasil berdasarkan klasifikasi $C T$ scan masih terbatas. Penelitian ini bertujuan untuk mengevaluasi hubungan antara kadar IL-6 serum dan klasifikasi CT Marshall pada pasien dengan COBT. Jenis penelitian ialah observasional dengan desain potong lintang. Hasil penelitian mendapatkan 20 pasien yang dirawat dengan COBT di IRDB RSUP Prof. Dr. R. D. Kandou Manado. CT-scan segera digunakan untuk menentukan klasifikasi CT Marshall dan untuk mengategorikan lokasi (ekstra-aksial, intra-aksial, keduanya), belahan (garis tengah/difus, dekstra, sisnitra), dan area otak yang terlibat dalam cedera. Sampel darah vena untuk IL-6 diambil kurang dari 24 jam setelah trauma. Hasil penelitian mendapatkan rerata kadar IL-6 22,0060 pg/mL (SD 4,64494 $\mathrm{pg} / \mathrm{mL}$ ). Pasien didistribusikan relatif seragam dalam empat kategori yang terdeteksi (difus cedera II, III, V, dan VI) dari klasifikasi CT Marshall. Model regresi akhir terdiri dari IL-6, usia, dan cedera pada area temporal sebagai prediktor. Korelasi antara kadar IL-6 serum dan klasifikasi CT Marshall dianalisis dengan koefisien korelasi Spearman dan mendapatkan rs = $0,005(P=0,491)$. Simpulan: Walaupun secara statistik tidak terdapat hubungan bermakna antara kadar Il-6 serum dan CT Marshall namun keduanya secara konsisten meningkat mengikuti COBT dan dapat menjadi prediktor potensial untuk menentukan prognosis pada pasien dengan COBT.
\end{abstract}

Kata kunci: IL-6, CT Marshall, COBT 
Cedera otak akibat trauma (COT) merupakan salah satu penyebab utama kematian pada kasus-kasus kecelakaan lalu lintas. COT itu sendiri merupakan cedera yang terjadi karena adanya tekanan mekanik eksterna yang mengenai kranium dan komponen intrakranial sehingga menimbulkan kerusakan sementara atau permanen pada otak, gangguan fungsional, atau gangguan psikososial. ${ }^{1,2}$

Telah diketahui bahwa terjadi perubahan berbagai proses neuroinflamatori pada neurotrauma. Berbagai agen pro dan anti-inflamasi seperti TNF, IL-1 $\beta$, IL6, IL-8, dan IL-10, telah diamati berfluktuasi sebagai respons terhadap COT; oleh karena itu telah diselidiki kemampuannya sebagai biomarker yang dipertimbangkan untuk diagnosis COT dan prognosis. ${ }^{1,6}$

Interleukin 6 (IL-6) telah banyak dipelajari sebagai penanda inflamasi di berbagai populasi. IL-6 adalah sitokin 20$30 \mathrm{kDa}$ dengan sifat pleiotropik yang telah terbukti menjadi biomarker dikaitkan dengan berbagai keadaan penyakit. Dalam susunan saraf pusat (SSP), IL-6 diekspresikan oleh astrosit, mikroglia, dan neuron. Pada manusia, IL-6 biasanya tidak terdeteksi dalam serum pada kondisi fisiologik normal. Peningkatan kadar IL-6 telah diamati pada kondisi patofisiologik dan diyakini sebagai indikasi kerusakan aksonal. Kadar IL-6 pada manusia telah dilaporkan secara akut, dan kadang-kadang terus-menerus, meningkat setelah suatu COT berat. Selain itu, analisis multipleks terbaru dari biomarker serum mengidentifikasi IL-6 sebagai penanda COT. Penelitian tersebut mendukung premis bahwa protein yang terkait dengan inflamasi seperti IL-6 meningkat mengikuti COT. $^{3,6}$

Karateristik imaging dari $C T$ scan kepala tanpa kontras dapat mengidentifikasi adanya atau perluasan dari kerusakan struktural pada penderita-penderita COT. Marshall computed tomography system (CT Marshall) adalah sistem klasifikasi neuroimaging yang paling luas digunakan dalam COT. Kegunaannya penting sebagai suatu variabel prognostik yang independen berdasarkan temuan-temuan pada CT scan, yaitu menggunakan status sisterna mesensefalika, tingkat pergeseran garis tengah dalam milimeter, ada tidaknya satu atau lebih massa pendarahan, dan akan dibedakan dalam enam kelompok yang berbeda. ${ }^{4,5}$

\section{METODE PENELITIAN}

Penelitian ini dilakukan pada subjek penelitian berjumlah 20 pasien COT berat yang masuk ke IRDB RSUP Prof. Dr. R. D. Kandou Manado sejak bulan Maret sampai Juni 2018 dengan kriteria inklusi onset trauma kurang dari 24 jam, usia 1645 tahun, dan COT dengan GCS 3-8. Kriteria eksklusi ialah pasien dengan riwayat COT sebelumnya, penyakit infeksi/ sistemik yang dapat mengganggu proses inflamasi, mengonsumsi zat yang dapat memengaruhi kesadaran atau inflamasi, atau dengan cedera penyerta lain (multitrauma).

Pasien yang memenuhi kriteria inklusi dilakukan pemeriksaan $C T$ scan kepala, dan dikelompokkan berdasarkan klasifikasi CT Marshall dan berdasarkan lokasi (ekstra-aksial, intra-aksial, keduanya), hemisfer (garis tengah/difus, dekstra, sinistra), dan area (frontal, parietal, temporal, oksipital, multipel) otak yang terkena dalam cedera. Kadar IL-6 serum diperoleh dari sampel darah vena dalam waktu kurang dari 24 jam pasca trauma.

Data yang dikumpulkan diolah menggunakan software statistik $\mathrm{R}$ versi 3.4.4. Analisis deskriptif untuk melihat distribusi variabel-variabel penelitian dilakukan secara univariat maupun bivariat.

\section{HASIL PENELITIAN}

Penelitian ini dilakukan IRDB RSUP Prof. Dr. R. D. Kandou Manado sejak bulan Maret sampai Juni 2018 pada 20 pasien COT berat yang memenuhi kriteria inklusi dan eksklusi.

Subjek penelitian ini sebanyak 20 pasien didominasi oleh laki-laki ( $\mathrm{n}=17$; $85 \%$ ) dengan rerata usia 32 tahun, usia terendah 16 tahun, usia tertinggi 45 tahun dengan SD 10,714 tahun. Tidak seluruh 
klasifikasi CT Marshall terdeteksi pada pasien-pasien ini, namun di antara kategori yang ada (II, III, V, dan VI) proporsinya relatif uniform, yaitu berturut-turut, $35 \%$, $30 \%, 10 \%$, dan $25 \%$.

Pemeriksaan $C T$ scan menunjukkan bahwa cedera kepala pada subjek terutama berlokasi di sekitar epidural, subaraknoid, atau subdural $(\mathrm{n}=15 ; 60 \%)$, dengan 10 orang lainnya (40\%) mengalami perdarahan dalam otak atau kombinasi ekstra-aksial dan intra-aksial. Umumnya cedera mengenai area temporalis walaupun sejumlah subyek mengalaminya pada beberapa area sekaligus (Tabel 1). Distribusi subyek penelitian berdasarkan klasifikasi CT
Marshall ditampilkan dalam Tabel 2.

Hasil pemeriksaan laboratorium memperlihatkan rerata kadar IL-6 serum sebesar $22,0060 \mathrm{pg} / \mathrm{mL}$, kadar terendah 14,38 $\mathrm{pg} / \mathrm{mL}$, kadar tertinggi $29,38 \mathrm{pg} / \mathrm{mL}$ dengan SD 4,64494 pg/mL (Tabel 3).

Hubungan CT Marshall dengan kadar IL-6 serum dianalisis dengan analisis koefisien korelasi Spearman dan diperoleh $\mathrm{r}_{\mathrm{s}}=-0,005$ dengan $P=0,491$. Hasil uji ini menyatakan bahwa secara statistik tidak terdapat hubungan bermakna antara CT Marshall dan kadar IL-6 serum. Hubungan nilai rerata IL-6 berdasarkan derajat CT Marshall dapat dilihat pada Tabel 3.

Tabel 1. Distribusi subyek penelitian berdasarkan lokasi perdarahan

\begin{tabular}{lcc}
\hline Lokasi perdarahan & Frekuensi & Persentase \\
\hline Edema serebri & 1 & 5,0 \\
EDH frontal dekstra & 1 & 5,0 \\
EDH frontal sinistra & 1 & 5,0 \\
EDH oksipital & 1 & 5,0 \\
EDH oksipital + SAH & 1 & 5,0 \\
EDH oksipital dekstra + SDH frontotemporal dekstra & 1 & 5,0 \\
EDH oksipital dekstra + SDH temporooksipital dekstra & 1 & 5,0 \\
EDH temporal dekstra & 1 & 5,0 \\
EDH temporal sinistra & 1 & 5,0 \\
EDH temporoparietal dekstra & 1 & 5,0 \\
ICH frontal & 1 & 5,0 \\
ICH frontal sinistra & 1 & 5,0 \\
ICH oksipital dekstra & 1 & 5,0 \\
ICH parietal dekstra & 2 & 10,0 \\
ICH parietal sinistra + SAH & 1 & 5,0 \\
ICH temporoparietal dekstra & 1 & 5,0 \\
SAH oksipital & 1 & 5,0 \\
SAH parietal dekstra & 1 & 5,0 \\
SDH temporal sinistra & 1 & 5,0 \\
Total & 20 & 100,0 \\
\hline
\end{tabular}

EDH, epidural hematoma; SDH, subdural hematoma, SAH, subarachnoidal hematoma; ICH, intracranial hemorrhage

Tabel 2. Distribusi subyek penelitian berdasarkan klasifikasi CT Marshall

\begin{tabular}{ccc}
\hline Klasifikasi & Frekuensi & Persentase \\
CT Marshall & & \\
\hline II & 7 & 35,0 \\
III & 6 & 30,0 \\
IV & 2 & 10,0 \\
V & 5 & 25,0 \\
Total & 20 & 100,0 \\
\hline
\end{tabular}


Tabel 3. Hubungan nilai rerata IL-6 berdasarkan derajat CT Marshall

\begin{tabular}{cccccc}
\hline Klasifikasi & \multicolumn{5}{c}{ Kadar IL-6 serum } \\
CT Marshall & N & Minimum & Maksimum & Rerata & SD \\
\hline 2 & 7 & 17,30 & 29,38 & 22,1657 & 4,33290 \\
3 & 6 & 14,38 & 28,04 & 21,4517 & 5,65321 \\
4 & 2 & 17,91 & 25,72 & 21,8150 & 5,52250 \\
5 & 5 & 16,33 & 28,28 & 22,5240 & 5,08826 \\
Total & 20 & 14,38 & 29,38 & 22,0060 & 4,64494 \\
\hline
\end{tabular}

\section{BAHASAN}

Pada penelitian ini didapatkan kadar IL-6 serum meningkat setelah terjadinya COT, dengan rerata kadar IL-6 serum $22,0060 \mathrm{pg} / \mathrm{mL}$ (SD 4,64494 pg/mL). Hal ini sesuai dengan yang telah dilaporkan oleh penelitian-penelitian sebelumnya yaitu kadar serum IL-6 akan meningkat dalam 2 jam sampai 3 hari setelah trauma. ${ }^{6}$ Nilai kadar serum IL-6 ini akan semakin meningkat pada cedera yang lebih buruk yang pada penelitian ini dikategorikan berdasarkan klasifikasi CT Marshall. Besar sampel yang terbatas dan variabel jenis kelamin yang tidak proporsional dapat berperan dalam kejadian ini, namun setelah faktor-faktor tersebut dipertahankan konstan, ditemukan bahwa pasien rata-rata mengalami peningkatan odds rasio untuk kategori CT Marshall lebih tinggi hampir dua kali lipat lebih besar. Kadar IL-6 serum yang tinggi cenderung mengarah pada luaran yang lebih buruk setelah COT, sehingga IL-6 dapat dijadikan sebagai nilai prognostik. ${ }^{6}$

Pada penelitian ini didapatkan sebanyak 20 subjek yang memenuhi kriteria inklusi dan diikut sertakan dalam penelitian. Hasil penelitian ini menunjukkan bahwa pasien laki-laki lebih banyak daripada perempuan, berusia antara 16 hingga 45 tahun, dan waktu datang onset ke rumah sakit kurang dari 24 jam setelah kejadian.

Pengukuran IL-6 secara statistik menunjukkan korelasi yang signifikan pada COBT yang ditentukan dengan klasifikasi CT Marshall. Hasil ini sesuai dengan temuan sebelumnya yang menunjukkan bahwa IL-6 diproduksi cepat setelah cedera otak yang menunjukkan tingkat keparahan cedera otak dimana terjadi kerusakan sawar darah otak dan atau komponen didalamnya yang berkorelasi dengan sitokin antiinflamasi setelah cedera otak. ${ }^{5}$ Pasien dengan kadar IL-6 serum $<20$ pg/ml, secara bermakna menunjukkan ketahanan hidup lebih besar dibandingkan dengan yang dengan kadar serum yang lebih tinggi $(P<0,01)$. Kadar IL-6 serum $>20 \mathrm{pg} / \mathrm{ml}$ setelah 30 jam pada COBT, dua kali lebih sering terkait dengan kematian daripada kadar serum yang lebih rendah. ${ }^{7}$

Hergenroeder et $\mathrm{al}^{8}$ berpendapat bahwa peningkatan kadar IL-6 serum menunjukkan prognosis yang buruk. Pada penderita multi trauma, IL-6 dapat dilepaskan ke dalam sirkulasi sebagai hasil cedera pada berbagai organ. Banyak tipe sel termasuk monosit, makrofag, fibroblas, keratinosit, serta sel $\mathrm{T}$ dan $\mathrm{B}$ telah menunjukkan peningkatan produksi IL-6 sebagai respon terhadap trauma. ${ }^{8}$

Potensi prognostik IL-6 memiliki kegunaan paling banyak dalam memrediksi angka kematian setelah COT meskipun masih kontroversial. Oleh karena itu diperlukan penentuan peran IL-6 di masa depan dalam memrediksi hasil lainnya. ${ }^{9}$

Pada penelitian ini kadar serum IL-6 terendah ialah $14,38 \mathrm{pg} / \mathrm{ml}$ dan tertinggi $29,38 \mathrm{pg} / \mathrm{ml}$ dengan rerata $22,060 \mathrm{pg} / \mathrm{ml}$. Kadar IL-6 meningkat dalam 24 jam pertama setelah cedera otak berat. Hal ini selaras dengan penelitian Hergenroeder et $\mathrm{al}^{8}$ yang menyatakan bahwa ekspresi IL-6 meningkat dalam 24 jam pertama setelah trauma kepala berat, dan konsisten dengan sifat pro-inflamasi.

Marshall et $\mathrm{al}^{4}$ mengusulkan CT klasifikasi untuk mengelompokkan pende- 
rita dengan cedera otak menurut beberapa karakteristik CT. Adanya pergeseran garis tengah $>5 \mathrm{~mm}$ pada awal $C T$ scan otak dan tinggi atau campuran kepadatan lesi $>25$ $\mathrm{mm}^{3}$ keduanya telah berkorelasi dengan ancaman kematian.

Istilah cedera otak difus pada klasifikasi CT Marhall dibagi menjadi empat sub kelompok, yang didefinisikan sebagai berikut: cedera difus I termasuk cedera otak semua difusi di mana tidak ada kelainan patologi terlihat; Cedera difus II mencakup semua cedera menyebar di mana sisterna yang ini, pergeseran garis tengah kurang dari $5 \mathrm{~mm}$, dan atau tidak ada tinggi atau lesi mixed density lebih dari $25 \mathrm{~mm}$; Cedera difus III meliputi cedera menyebar dengan pembengkakan di mana sisterna yang dikompresi atau tidak dan pergeseran garis tengah adalah 0-5 mm tanpa lesi tinggi atau campuran kepadatan lebih dari $25 \mathrm{~mm}^{3}$; cedera difus IV dimana ditemukan lesi padat dan memerlukan tindakan operatif. ${ }^{4,10}$ Marshall et $\mathrm{al}^{4}$ berkesimpulan bahwa semakin tinggi kategori CT Marshall maka semakin buruk prognosis.

Pada penelitian ini didapatkan bahwa penderita COBT dengan cedera difus $\mathrm{V}$ pada 5 pasien $(25 \%)$; cedera difus IV pada 2 pasien $(10 \%)$; cedera difus III pada 6 pasien $(30 \%)$; dan cedera difus II pada 7 pasien $(35 \%)$. Dapat disimpulkan bahwa data ini sesuai dengan pendapat Marshall et $\mathrm{al}^{4}$ yaitu semakin tinggi derajat CT Marshall maka akan semakin buruk prognosisnya.

Hubungan CT Marshall dengan IL-6 dianalisis dengan analisis koefisien korelasi Spearman yang memperoleh $r_{s}=-0,005$ dengan $P=0,491$. Hasil uji ini menyatakan bahwa secara statistik tidak terdapat hubungan bermakna antara CT Marshall dan IL-6 namun pada penelitian ini ditemukan bahwa terdapat peningkatan IL6 serum pada pasien COT dengan GCS berat seiring bertambah beratnya derajat CT Marshall.

Dari penelitian ini dapat diketahui bahwa kadar IL-6 yang tinggi cenderung mengarah pada luaran yang lebih buruk setelah COT sehingga IL-6 dapat dijadikan sebagai nilai prognostik. Semakin tinggi tingkat kerusakan yang tampak pada CT Marshall, maka akan semakin buruk juga prognosisnya.

\section{SIMPULAN}

Walaupun secara statistik tidak terdapat hubungan yang bermakna antara CT Marshall dan IL-6 namun nilai IL-6 dan klasifikasi CT Marshal akan meningkat pada pasien dengan COBT dan dapat menjadi prediktor potensial untuk menentukan prognosis pada pasien tersebut.

\section{DAFTAR PUSTAKA}

1. Friede TR, Houry D, Baldwin G. Centers for Disease Control and Prevention. Report to Congress on Traumatic Brain Injury in the United States: Epidemiology and rehabilitation. National Center for Injury Prevention and Control; Division of Unintentional Injury Prevention. Atlanta, GA. 2015: 2

2. Manarisip MEI, Oley MCh, Limpeleh H. Gambaran CT scan kepala pada penderita cedera kepala ringan di BLU RSUP Prof. Dr.R.D. Kandou Manado periode 2012-2013. eCl. 2014;2(2).

3. Menon DK, Schwab K, Wright DW, Maas Al. Position statement: definition of traumatic brain injury. Arch Phys Med Rehabil. 2010;91(11):1637-40.

4. Marshall LF, Marshall SB, Klauber MR, Van Berkum Clark M, Eisenberg H, Jane JA, et al. A new classification of head injury based on computerized tomography. Journal of Neurosurgery. 1991;75:S14-S20.

5. Raj R. Prognostic models in traumatic brain injury [Disertasi]. Finland: Finland University of Helsinki; 2014; p. 2-25.

6. Yousefzadeh-Chabok S, Moghaddam AD, Kazemnejad-Leili E, Saneei Z, Hosseinpour M, et al. The relationship between serum levels of interleukins 6 , 8,10 and clinical outcome in patients with severe traumatic brain injury. Arch Trauma Res. 2015;4(1):e18357

7. Gennarelli TA. Mechanisms of brain injury. J Emerg Med. 1993;11(Supl 1): 5-11.

8. Hergenroeder GW, Moore AN, McCoy JP, Ward NH, Clifton GL, Dash PK. Serum IL-6: a candidate biomarker for intracranial pressure elevation follow-ing 
46 Jurnal Biomedik (JBM), Volume 11, Nomor 1, Maret 2019, hlm. 41-46

isolated traumatic brain injury. J Neuroinflammation. 2010;7:19.

9. Timmerman KL, Amonette WE, Markofski MM, Ansinelli HA, Gleason EA, Rasmussen BB, et al. Blunted IL-6 and IL-10 response to maximal aerobic exercise in patients with traumatic brain injury. Eur J Appl Physiol. 2015;115(1):111-8.

10. Zhu GW, Wang F, Liu WG. Classification and prediction of outcome in traumatic brain injury based on computed tomographic imaging. J Int Med Res. 2009;37(4):983-95. 